\title{
The Role of Electronic Means in Enhancing the Intellectual Security among Students at the University of Jordan
}

\author{
Mohammad Salim Al-Zboun ${ }^{1}$, Mamon Salim Al-Zboun ${ }^{2}$, Hussam N. Fakhouri ${ }^{3}$ \\ School of Educational Science, The University of Jordan, Amman, Jordan ${ }^{1,2}$ \\ School of Art and Design, The University of Jordan, Amman, Jordan ${ }^{3}$
}

\begin{abstract}
The study aims to identify the role of electronic means in enhancing intellectual security among students at the University of Jordan. To achieve the objective of the study, a study instrument is developed, and the study sample consists of (525) male and female students. The results show that the response of the university students in assessing the role of electronic means in enhancing the students' intellectual security is with an arithmetic mean of (3.07), and a standard deviation of (1.128), and this score is considered medium. In light of the results of the study, the researchers recommend employing electronic means in activating the intellectual security among the university education students in Jordan.
\end{abstract}

Keywords-Electronic means; intellectual security; enhancement

\section{INTRODUCTION}

The information technology sector and electronic means in the eyes of many thinkers, decision-makers and educators represent a golden opportunity for developing countries to achieve development in all its forms if it is properly utilized and employed. Electronic means have recently occupied a prominent place among the measures that indicate the level of civilization and progress in any country in the world, as they constitute an independent strength society. The governments have realized the effective and large role of electronic means due to their influencing power and ability to affect the opinion of the public in society and stimulate them to defend certain standpoints required by them, and thus giving it great attention. Currently, electronic means play an unprecedented role in the issue of enhancing intellectual security. It has a tremendous capacity to educate local citizens, serving as a primary hub in spreading knowledge.

All opinions contribute to the importance of the great role that electronic means occupy in the lives of individuals and groups, and the extent of their influence on their life, economic, social and cultural affairs, and in enriching the knowledge stock and expanding their perception's space. Electronic means are the main source of intellectual, spiritual, educational, and cultural wealth and constitute a large portion of their interest [1].

Hereafter, it is necessary to realize the great and important role of electronic means, especially in light of technical and technological advances, and the information revolution by employing them in a good manner, whether they are readable or audible. Importantly, the optimal use of electronic means helps clarify visions, provide students with information, facts, and experiences, and qualify them in crystallizing their thoughts and opinions in front of the latest developments to take the appropriate and logical positions that lead to their growth and development [2].

In light of these developments and growths, the importance of intellectual security lies in achieving security and stability in the society by addressing intellectual influences and deviations. Intellectual empowerment becomes one of the priorities that support security planning in Arab society in its current and future stage that protects individuals from intellectual influences which is considered a fundamental necessity in its security, stability, and social and economic prosperity [3].

Therefore, it is essential to pay attention to intellectual security, which aims to make individuals in their society live in full security and reassurance about the components of their personality and the distinctiveness of their culture and their intellectual system stemming from the Holy Qur'an and Sunnah. This means protecting and preserving the Islamic identity from penetration or containment from outside and preserving the security of the nation from the winds of delinquency of the approach of moderation in light of the tremendous momentum of the means of intellectual and cultural invasion. The importance of intellectual security comes from its goal of the integrity of faith, the integrity of behavior, and the proof of loyalty that is the basis of its existence and the reason for its glory and pride [4].

The significance of intellectual security lies in its association with two important matters: security and thought. Security is considered a requirement that all societies strive to achieve, and life is not satisfied without it, while the thought is the beating heart of the civilizations, the more the thought carried by society is healthy and conscious, the more it produces and innovates. Importantly, security and thought do not settle without achieving the intellectual security of the members of society as previously confirmed that no doubt achieving the intellectual security of the individual will ensure an automatic verification of security in all aspects because the mind is the body of the distinctive supreme conscious leadership in the human being and it is the lead agency entrusted with all other types of security. If this leadership is 
correct and flawless, then all the members of the security family are correct and flawless [5].

Notably, the issue of intellectual security has become one of the vital and important issues, and the degree of sensitivity it acquires in the lives of peoples and the future of nations necessitates addressing it as it is a basic and contemporary issue and it is inevitable to confront it in light of the facts of the conditions in which the Arab and Islamic nation is living and the tensions that have resulted in the emergence of the two phenomena of cultural alienation and the ideological extremism. It is agreed that intellectual security is the existing or supposed harmony between what societies believe and what they live in the vocabulary of their daily life and what they aspire to. Achieving the said harmony is based on the agreement existing among individuals in relying on a mutual cultural and doctrinal reference that represents the main features of the background in which society believes in its various sects and the multiplicity of its cultural and political textures. Society still needs intellectual security to bring citizens together on one word as achieving intellectual security is the responsibility of society with all its components to unite around one basic idea about the faith and the homeland. Also, it should not be understood that intellectual security means a blockade and a restriction of the mind, but rather an affirmation of freedom of opinion within the framework of respecting the principles of the nation and conserving and protecting its heritage from attempts to defame the identity of the foreign cultural invasion that destroys the foundations and authenticity of society. More importantly, intellectual security is the pillar of the rise of nations and societies and the guarantor of providing the security of people and the country from the dangers of alienation [6].

In light of the above, the electronic means strengthening the intellectual security of university students has become important, especially at present, due to several contemporary international variables such as scientific and industrial development, the globalization of markets, the information revolution, and the development and technological advancement of electronic means.

\section{EASE OF THE PROBlem OF THE STUdy}

In light of the aforesaid insight, the problem of the study lies in examining the role that electronic means play in enhancing the intellectual security among students at the University of Jordan students.

\section{QUESTIONS OF THE STUDY}

In light of the problem of the Study, the following questions are articulated.

1) What is the role of electronic means in enhancing the intellectual security of students at the University of Jordan?

2) Are there statistically significant differences at the level of $(a \leqslant 0.05)$ in the role of electronic means in enhancing intellectual security among the students at the University of Jordan due to the following variables (gender, specialization, academic level)?

\section{OBJECTIVES OF THE STUdy}

The following objectives are formatted to answer the questions of the study.

1) Identify the role of electronic means in enhancing the intellectual security of students at the University of Jordan.

2) Examine if there are statistically significant differences at the level of $(\alpha \leqslant 0.05)$ in the role of electronic means in enhancing intellectual security among the students at the University of Jordan due to the following variables (gender, specialization, academic level).

\section{SignificANCE OF THE STUdY}

The significance of the current study is seen in the results of this study that reveal the reality of the role of electronic means in enhancing intellectual security among students at the University of Jordan. It is also hoped that the results of the current study will contribute to developing the role of electronic means in enhancing the intellectual security of students. Moreover, the current research paper sheds light on an important issue in society, which is intellectual security, where intellectual security is of great importance to ensure the security and stability of society.

\section{TERMS OF THE STUDY}

Electronic means: they are the means made through electronic methods such as the Internet, and this type of means is gaining a growing share and status. This is a result of its ease of accessibility, speed of production, development, and modernization. Social networking sites such as Facebook, Instagram, WhatsApp, electronic newsletters, and television are the most important forms of electronic means [7].

Intellectual security: it is the ability and preservation of the integrity of the correct ideas and beliefs of individuals while providing them with research tools, knowledge, and methods of correct thinking, and this is achieved and complemented by the course of literature, education and good communication [8].

\section{LIMITATIONS OF THE STUDY}

This study is limited to a sample of students at the University of Jordan during the first semester of the academic year 2019/2020. Concerning the methodological limitations, the results of the study are determined with the validity and reliability of its instrument, and the accurate response of the study sample individuals to the items of the instrument used to collect its data. The results of the study are generalized to the study population from which the study sample is taken.

\section{PREVIOUS STUdIES}

1) Several studies have been written on the importance of electronic means and intellectual security in people's life. Jounson (2005) aims at identifying the features of intellectual security for students provided by the Internet in Mankato city in the state of Minnesota in the United States of America. The study indicates that this city can meet security requirements and allow employees and students to enter the greatest sources on the Internet. The study shows that $81 \%$ of students have 
achieved the intellectual security features in terms of freedom to express opinion objectively via the Internet, use the Internet in education, and search for information and knowledge that provides these students with a tremendous amount of information which leads to achieving the aspired intellectual and information security. Radwan, Ramadan, and Abdulwahab (2010) aim at identifying the role of modern communication technology in developing freedom of expression of opinion among university students. To achieve the above objective, the study has used the descriptive approach and the content analysis method to analyze some of the codes of some student movements. The study shows that tremendous development in communication technology has helped to form a new standard community which is called the virtual community [9][10].

2) Kuppuswamy and Narayan (2010) have aimed to examine the impact of social networking sites on youth education. The study shows that young people are attracted to social network sites that have a positive effect on them, but they may lead to students not being interested in their studies. However, these sites can be used in education if they are used in light of sound educational principles and appropriate supervision by teachers [11].

3) Shaltan (2013) aims to identify the role of colleges of education in Palestinian universities in enhancing intellectual security for their students and ways to activate it. To achieve this objective, the study has used descriptive and analytical approaches [12]. The results of the study indicate that the students 'estimates of the role of colleges of education in Palestinian universities in enhancing intellectual security among their students are $(72.23 \%)$. The study also shows that there are statistically significant differences between the arithmetic means of the sample responses due to the gender variable (male and female) in the first and second areas, where the differences are in favor of males. The study also shows that there are statistically significant differences between the arithmetic means of the sample responses due to the variable of the university (The Islamic University of Gaza, Al-Aqsa University) in all fields and the total degree in favor of the Islamic University. Also, the study shows that there are no statistically significant differences between the arithmetic means of the sample responses due to the academic level variable (second year, fourth year). Moreover, the study shows there are statistically significant differences attributed to the GPA variable (Pass, good, very good, excellent) for all fields and the total degree in favor of excellence. Abu Khotwa and Baz (2014) have aimed to identify the implications of the social network on the intellectual security of university education students in the Kingdom of Bahrain. The study has used the descriptive approach and a questionnaire applied to a sample of (104) male and female students at the Gulf University in the Kingdom of Bahrain. The results of the study show that the impact of social media networks on students' intellectual security, in general, is of a medium degree, which confirms the need to work on educating students in the different educational stages of the uses of social networks and work to develop their critical thinking so that they can sort out the ideas and opinions presented to them, and not be misled by the destructive calls that harm the stability and security of society. The study commends presenting a proposed vision for employing the social network to activate intellectual security among university education students in the Kingdom of Bahrain [13][14][15].

In light of the results of previous studies, it is noted that they have generally dealt with many issues about the role of electronic means in developing freedom of opinion and expression and intellectual security without addressing the role of electronic means in enhancing intellectual security among Jordanian university students. The previous studies presented are closely related to the current study, as it aims to enhance the intellectual security of university students by highlighting the need to pay attention to electronic means as one of the means to enhance intellectual security, activate its role in developing students' intellectual security, and increase their knowledge and active participation in the community. Importantly, the current study has benefited from previous studies in several aspects such as identifying the role of electronic means in enhancing intellectual security and in constructing the current study instrument. However, what distinguishes this study from other studies is that it is considered one of the first studies according to the researchers' knowledge that aims to identify the role of electronic means in enhancing intellectual security among Jordanian university students [16] [17].

\section{Methodology OF THE Study}

This part of the study includes a presentation of the methodology, study population. The study sample, study instrument, methods for ensuring its validity and reliability, the study procedures followed to attain the results, and the statistical processing used in analyzing the data. This study is considered a descriptive and analytical study. To obtain data related to the role of electronic means in enhancing intellectual security among the students at the University of Jordan, a representative sample of the students of the University of Jordan, which forms the study population, is selected.

1) Study population: The study population consists of all undergraduate students at the University of Jordan in the first semester of the academic year 2019/2020.

2) Study sample: As for the study sample, it is selected according to the simple random sampling method, which gives everyone in the study population equal opportunities, where the number of sample members is (525) male and female students at the University of Jordan as illustrated in Table I. 
TABLE I. FREQUENCIES AND PERCENTAGES ACCORDING TO STUDY VARIABLES

\begin{tabular}{|l|l|l|l|}
\hline Variable & Category & Number & Percentage \\
\hline \multirow{4}{*}{ Gender } & Male & 242 & 46.0 \\
\cline { 2 - 4 } & female & 283 & 54.0 \\
\cline { 2 - 4 } & Total & 525 & 100.0 \\
\hline \multirow{5}{*}{ Academic Level } & scientific & 249 & 47.0 \\
\cline { 2 - 4 } & Humanities & 276 & 53.0 \\
\cline { 2 - 4 } & Total & 525 & 100.0 \\
\hline & First year & 87 & 16.5 \\
\cline { 2 - 4 } & Second Year & 120 & 22.8 \\
\cline { 2 - 4 } & Third year & 143 & 27.4 \\
\cline { 2 - 4 } & Fourth year & 175 & 33.3 \\
\cline { 2 - 4 } & Total & 525 & 100.0 \\
\hline
\end{tabular}

\section{Methodology of The Study}

This part of the study includes a presentation of the methodology, study population. The study sample, study instrument, methods for ensuring its validity and reliability, the study procedures followed to attain the results, and the statistical processing used in analyzing the data. This study is considered a descriptive and analytical study. To obtain data related to the role of electronic means in enhancing intellectual security among the students at the University of Jordan, a representative sample of the students of the University of Jordan, which forms the study population, is selected.

\section{OBJECTIVE OF THE STUDY}

To achieve the objectives of the study, the theoretical literature and previous studies addressing intellectual security such as the study of Abu Khotwa and Baz (2014) and other related studies are reviewed in detail. The questionnaire in its initial form consists of (34) items. The Likert five-level measure is used to (Strongly disagree, Disagree, Neither agree nor disagree, Agree, Strongly Agree.

The five-step Likert scale is used to determine the degree of response of the sample members to the study instrument, where a numerical estimate (1-5) is given for those responses as follows: Strongly agree (5 grades), agree (4 grades), neither agree nor disagree (3 grades), strongly disagree (2 grades), disagree (1 degree). The following measure is adopted to analyze the results:

From 1.00 to 2.33 low

From 2.34 to 3.67 medium

From 3.68 to 5.00 is high

\section{INSTRUMENT VALIDITY}

To verify the validity of the study instrument, it is presented to 10 experts and specialists in the fields of education technology, curricula, teaching, measurement, and evaluation to express their opinions on it in terms of the degree of appropriateness of the items in terms of their language, suitability to the field, the degree of their achievement of the objective for which they are set, and the opinions of the validators are taken in terms of deletion, amendment, and addition, and then the final formulation of the questionnaire is articulated.

\section{INSTRUMENT RELIABILITY}

To verify the reliability of the instrument, the test and retest method is used, where it is applied to a group from outside the study sample consisting of (20) students, and after ten days of applying the questionnaire, the same instrument is applied to the same group. Then, the reliability coefficient is calculated using the Cronbach alpha coefficient equation between the two applications, as the reliability coefficient for the study instrument has reached (0.92). In light of this result, it can be said that the study instrument has high reliability suitable for this type of study.

\section{RESULTS AND DISCUSSION}

This section gives an insight into the study's results and discussion as follows:

Q1. What is the role of electronic means in enhancing the intellectual security of students at the University of Jordan?

To answer this question, the arithmetic means and standard deviations are calculated as illustrated in Table II.

Table II shows that the arithmetic means have ranged (2.35-3.67), where the item (27) which states "The University's web pages encourage obedience to laws and regulations" is ranked first with an arithmetic mean of (3.67) with a medium degree. This may be because those in charge of the university's electronic pages understand the important role that these pages and websites play in achieving intellectual security, which motivates them to create electronic pages capable of meeting the requirements of all students seeking to reach a higher level of the cultural development. It is also attributed to the idea that these electronic pages belonging to the university have awareness of the importance of regulations and laws, which enhance teamwork among students, gain them various skills, and increase their belonging to the society in which they live. These electronic pages also invite students to pay attention to regulations and laws and adhere to them to raise the level of their performance and the mechanism of benefiting from the available means and working to educate students positively so that they are moderate by taking the causes and not neglecting them, and by developing their moral behavior, as they gain virtues and move away from vices, as they destroy society. These values must be encouraged to do good deeds and cooperation and form an open and interactive personality with society and other civilizations. 
TABLE II. FREQUENCIES AND PERCENTAGES ACCORDING TO STUDY VARIABLES

\begin{tabular}{|c|c|c|c|c|c|}
\hline Rank & No & Item & $\mathrm{AM}$ & SD & Level \\
\hline 1 & 27 & $\begin{array}{l}\text { The university's web pages } \\
\text { encourage obedience to laws } \\
\text { and regulations. }\end{array}$ & 3.67 & 0.66 & Medium \\
\hline 2 & 16 & $\begin{array}{l}\text { The university's electronic } \\
\text { pages develop sound thinking } \\
\text { methods to confront the } \\
\text { intellectual invasion. }\end{array}$ & 3.66 & 0.68 & Medium \\
\hline 3 & 14 & $\begin{array}{l}\text { The University of Jordan Radio } \\
\text { encourages cooperation with } \\
\text { community institutions by } \\
\text { exchanging visits to achieve } \\
\text { national unity. }\end{array}$ & 3.64 & 0.74 & Medium \\
\hline 4 & 1 & $\begin{array}{l}\text { Electronic newsletters develop } \\
\text { positive and behavioral trends } \\
\text { towards community security. }\end{array}$ & 3.62 & 0.75 & Medium \\
\hline 5 & 5 & $\begin{array}{l}\text { The University of Jordan pages } \\
\text { display activities aimed at } \\
\text { protecting students from } \\
\text { intellectual deviation }\end{array}$ & 3.60 & 0.78 & Medium \\
\hline 6 & 17 & $\begin{array}{l}\text { The University of Jordan Radio } \\
\text { develops the skills of scientific } \\
\text { research, investigation and } \\
\text { problem solving. }\end{array}$ & 3.57 & 0.80 & Medium \\
\hline 7 & 34 & $\begin{array}{l}\text { Electronic newsletters help } \\
\text { maintain public order and } \\
\text { achieve security, reassurance } \\
\text { and stability in life. }\end{array}$ & 3.55 & 0.83 & Medium \\
\hline 8 & 29 & $\begin{array}{l}\text { The University of Jordan Radio } \\
\text { promotes pride in the nation's } \\
\text { achievements. }\end{array}$ & 3.53 & 0.84 & Medium \\
\hline 9 & 28 & $\begin{array}{l}\text { Facebook for the University of } \\
\text { Jordan helps students to } \\
\text { become aware of the } \\
\text { Kingdom's pivotal role in the } \\
\text { religious, Arab, regional and } \\
\text { international levels. }\end{array}$ & 3.50 & 0.89 & Medium \\
\hline 9 & 33 & $\begin{array}{l}\text { Jordanian radio channels } \\
\text { educate the importance of } \\
\text { caring for work values in } \\
\text { society. }\end{array}$ & 3.50 & 0.88 & Medium \\
\hline 10 & 11 & $\begin{array}{l}\text { Facebook of the University of } \\
\text { Jordan promotes solidarity and } \\
\text { unity. }\end{array}$ & 3.48 & 0.90 & Medium \\
\hline 11 & 8 & $\begin{array}{l}\text { Public Security Radio spreads } \\
\text { awareness of society's } \\
\text { problems and its negative } \\
\text { aspects. }\end{array}$ & 3.47 & 0.92 & Medium \\
\hline 12 & 10 & $\begin{array}{l}\text { Twitter promotes the collective } \\
\text { values of students. }\end{array}$ & 3.44 & 0.97 & Medium \\
\hline 13 & 4 & $\begin{array}{l}\text { The University of Jordan Radio } \\
\text { provides educational activities } \\
\text { to confront intellectual } \\
\text { deviation. }\end{array}$ & 3.39 & 0.99 & Medium \\
\hline 14 & 6 & $\begin{array}{l}\text { Obtaining scientific } \\
\text { knowledge, media and news } \\
\text { from Jordanian radio channels. }\end{array}$ & 3.18 & 1.01 & Medium \\
\hline 15 & 12 & $\begin{array}{l}\text { Army Radio provides } \\
\text { assistance to students in being } \\
\text { positive members of society } \\
\text { without harming themselves. }\end{array}$ & 3.14 & 1.03 & Medium \\
\hline 16 & 13 & $\begin{array}{l}\text { Snapchat helps gain effective } \\
\text { communication skills. }\end{array}$ & 3.13 & 1.04 & Medium \\
\hline
\end{tabular}

\begin{tabular}{|c|c|c|c|c|c|}
\hline 17 & 9 & $\begin{array}{l}\text { Instagram helps identify } \\
\text { students' family problems. }\end{array}$ & 3.09 & 1.19 & Medium \\
\hline 18 & 24 & $\begin{array}{l}\text { Radio channels encourage } \\
\text { students to engage in dialogue } \\
\text { and discussion in resolving } \\
\text { political disputes. }\end{array}$ & 3.08 & 1.10 & Medium \\
\hline 19 & 30 & $\begin{array}{l}\text { Jordanian radio channels } \\
\text { explain the importance of } \\
\text { achieving economic security in } \\
\text { society. }\end{array}$ & 3.03 & 1.23 & Medium \\
\hline 20 & 22 & $\begin{array}{l}\text { Radio University of Jordan } \\
\text { promotes pride in the } \\
\text { dimensions of human } \\
\text { civilization in the Arab and } \\
\text { Islamic fields. }\end{array}$ & 3.01 & 1.26 & Medium \\
\hline 21 & 32 & $\begin{array}{l}\text { The university's electronic } \\
\text { pages provide preventive } \\
\text { methods to confront corruption } \\
\text { that negatively affects sound } \\
\text { thought. }\end{array}$ & 2.89 & 1.20 & Medium \\
\hline 22 & 21 & $\begin{array}{l}\text { The university's electronic } \\
\text { pages help students to confront } \\
\text { the ideological deviations } \\
\text { broadcast through the various } \\
\text { media. }\end{array}$ & 2.81 & 1.33 & Medium \\
\hline 23 & 19 & $\begin{array}{l}\text { The electronic bulletins aim to } \\
\text { build positive attitudes and } \\
\text { values towards the dimensions } \\
\text { of the concept of intellectual } \\
\text { security and its practices. }\end{array}$ & 2.83 & 1.22 & Medium \\
\hline 24 & 18 & $\begin{array}{l}\text { Jordanian radio channels help } \\
\text { create a culture of knowledge } \\
\text { about the concepts of } \\
\text { intellectual security. }\end{array}$ & 2.62 & 1.62 & Medium \\
\hline 25 & 3 & $\begin{array}{l}\text { The television airs examples of } \\
\text { educational thinkers to } \\
\text { emulate. }\end{array}$ & 2.58 & 1.69 & Medium \\
\hline 26 & 7 & $\begin{array}{l}\text { The University of Jordan Radio } \\
\text { listens to students' problems } \\
\text { and discusses them with them. }\end{array}$ & 2.55 & 1.23 & Medium \\
\hline 27 & 25 & $\begin{array}{l}\text { The television airs topics that } \\
\text { deepen the concepts of loyalty } \\
\text { and belonging to the homeland. }\end{array}$ & 2.54 & 1.21 & Medium \\
\hline 28 & 20 & $\begin{array}{l}\text { WhatsApp promotes the } \\
\text { security culture. }\end{array}$ & 2.49 & 1.85 & Medium \\
\hline 29 & 23 & $\begin{array}{l}\text { Public Security Radio promotes } \\
\text { the culture of sacrifice, the } \\
\text { presentation of the public } \\
\text { interest, and the rejection of } \\
\text { deviant cultures. }\end{array}$ & 2.47 & 1.34 & Medium \\
\hline 30 & 31 & $\begin{array}{l}\text { Public Security Radio promotes } \\
\text { positive economic interaction } \\
\text { with society. }\end{array}$ & 2.45 & 1.32 & Medium \\
\hline 31 & 15 & $\begin{array}{l}\text { Facebook of the University of } \\
\text { Jordan displays examples of } \\
\text { positive cultural intellectual } \\
\text { currents. }\end{array}$ & 2.43 & 1.31 & Medium \\
\hline 32 & 26 & $\begin{array}{l}\text { University of Jordan Radio } \\
\text { advises students to stay clear of } \\
\text { violence, extremism and } \\
\text { terrorism. }\end{array}$ & 2.42 & 1.31 & Medium \\
\hline 33 & 2 & $\begin{array}{l}\text { Facebook rejects deviant ideas } \\
\text { about society. }\end{array}$ & 2.35 & 1.13 & Medium \\
\hline & 27 & Total Degree & 3.07 & 1.128 & Medium \\
\hline
\end{tabular}


However, item (2) which states "Facebook rejects deviant ideas about society", is the lowest arithmetic means with an arithmetic mean of (2.35) with a medium degree. Then, item (26) which states "The University of Jordan Radio advises students to stay clear of violence, extremism and terrorism is with an arithmetic mean of (2.42), with a medium degree, followed by item (15) with an arithmetic mean of (2.43), and with a medium degree, which states, 'Facebook of the University of Jordan displays examples of positive cultural intellectual currents' ". The general arithmetic mean of the items that measure the role of electronic means in enhancing the intellectual security of Jordanian university students from the students' point of view is (3.07) with a medium degree. This result is in agreement with the findings of the study of Abu Khotwa and Baz (2014), which shows that the effect of social networks on the intellectual security of students, in general, is of medium degree.

Importantly, this is because electronic means in general, including university's webpages and Facebook, still lack awareness of students in different educational stages of the importance of intellectual security and the development of critical thinking so that they can sort out the ideas and opinions presented to them, and not be misled by destructive calls that harm the stability and security of the society. Also, universities are unwilling to involve themselves in sensitive topics that may contribute to creating future problems, especially since some websites are prohibited from broadcasting not only in the university, but in society, and this certainly reflects on the quality of the programs and the people who are hosted, alongside students' preoccupation with studying and exams, lack of critical thinking skills such as dialogue and discussion, as well as the conviction of their limited role in influencing and changing reality, which affects their understanding of the contents of the programs broadcast by electronic means.

Q2. Are there statistically significant differences at the level of $(a \leqslant 0.05)$ in the role of electronic means in enhancing intellectual security among the students at the University of Jordan due to the following variables (gender, specialization, academic level)?

To answer this question, the arithmetic means and standard deviations are calculated and a 3-way analysis of variance (ANOVA) is applied to reveal the differences in the role of electronic means in enhancing intellectual security due to variables (gender, specialization, and academic level) as illustrated in Table III. The following are the results.

Table III shows that there are apparent differences between the arithmetic means of the role of electronic means in enhancing intellectual security depending on the variables (gender, specialization, and academic level). To reveal the statistical significance of these differences, a 3-way analysis of variance (ANOVA) analysis is applied as illustrated in Table IV.

Table IV shows that there are no statistically significant differences at the level of significance $(\alpha \leqslant 0.05)$ in the role of electronic means in enhancing intellectual security according to the (gender) variable, as the value of (f) does not reach the level of statistical significance (0.05). It also shows that there statistically significant differences at the level of significance $(0.05)$ in the role of electronic means in enhancing intellectual security according to the variable of specialization, as the value of (f) is (3.432) with statistical significance of (0.058). This is due to the state of awareness formed in Jordanian society as a result of the technological revolution, developments, and the knowledge revolution. The electronic means in offering educational programs neither distinguish between males and females nor based on specialization because intellectual security is a humanitarian necessity for everyone involved in it without exception. It also shows that there are statistically significant differences at the level of significance (0.05) in the role of electronic means in enhancing intellectual security according to the variable of the academic level, as the value of (f) is (3.953) at the level of statistical significance $(0.00)$. To reveal the points of the differences, a Scheffe test is applied as illustrated in Table V.

TABLE III. ARITHMETIC MEANS AND STANDARD DEVIATIONS OF THE ROLE OF ELECTRONIC MEANS IN ENHANCING INTELLECTUAL SECURITY FOR STUDENTS AT THE UNIVERSITY OF JORDAN ARRANGED IN DESCENDING ORDER ACCORDING TO THE VARIABLES (GENDER, SPECIALIZATION, AND ACADEMIC LEVEL)

\begin{tabular}{|l|l|l|l|}
\hline Variable & Category & AM & SD \\
\hline \multirow{3}{*}{ Gender } & Male & 3.48 & 0.48 \\
\cline { 2 - 4 } & female & 3.66 & 0.44 \\
\hline \multirow{4}{*}{ Specialization } & scientific & 3.52 & 0.46 \\
\cline { 2 - 4 } & Humanities & 3.38 & 0.59 \\
\hline \multirow{4}{*}{} & First year & 3.43 & 0.56 \\
\cline { 2 - 4 } & Second Year & 3.49 & 0.45 \\
\cline { 2 - 4 } & Third year & 3.60 & 0.43 \\
\cline { 2 - 4 } & Fourth year & 3.44 & 0.55 \\
\hline
\end{tabular}

TABLE IV. RESUlts of (F) VALUES TO REVEAL DiFFERENCES IN THE ROLE OF ELECTRONIC MEANS IN ENHANCING INTELLECTUAL SECURITY DUE TO VARIABLES (GENDER, SPECIALIZATION, AND ACADEMIC LEVEL)

\begin{tabular}{|l|l|l|l|l|l|}
\hline $\begin{array}{l}\text { Source of } \\
\text { Variance }\end{array}$ & $\begin{array}{l}\text { Sum of } \\
\text { Squares }\end{array}$ & $\begin{array}{l}\text { Degrees of } \\
\text { Freedom }\end{array}$ & $\begin{array}{l}\text { Mean of } \\
\text { Squares }\end{array}$ & F & $\begin{array}{l}\text { Statistical } \\
\text { Sig. }\end{array}$ \\
\hline Gender & 0.059 & 1 & 0.059 & 0.245 & 0.512 \\
\hline Specialization & 0.781 & 1 & 0.781 & 3.432 & 0.058 \\
\hline $\begin{array}{l}\text { Academic } \\
\text { Level }\end{array}$ & 0.944 & 3 & 0.944 & 3.953 & 0.000 \\
\hline Error & 95.363 & 520 & 0.18 & & \\
\hline $\begin{array}{l}\text { Total } \\
\text { Adjusted }\end{array}$ & 96.589 & 525 & & & \\
\hline
\end{tabular}

TABLE V. SCHEFFE TEST RESUlTS TO REVEAL THE POINTS OF DIFFERENCES ON THE ACADEMIC LEVEL VARIABLE IN THE ROLE OF ELECTRONIC MEANS IN ENHANCING INTELLECTUAL SECURITY

\begin{tabular}{|l|l|l|l|l|l|}
\hline $\begin{array}{l}\text { Academic } \\
\text { Level }\end{array}$ & AM & $\begin{array}{l}\text { First } \\
\text { Year }\end{array}$ & $\begin{array}{l}\text { Second } \\
\text { Year }\end{array}$ & $\begin{array}{l}\text { Third } \\
\text { Year }\end{array}$ & $\begin{array}{l}\text { Fourth } \\
\text { Year }\end{array}$ \\
\hline First Year & 3.43 & - & $0.05-$ & $0.17-*$ & 0.00 \\
\hline $\begin{array}{l}\text { Second } \\
\text { Year }\end{array}$ & 3.49 & & - & $0.12-$ & 0.05 \\
\hline Third Year & 3.60 & & & - & $0.18^{*}$ \\
\hline $\begin{array}{l}\text { Fourth } \\
\text { Year }\end{array}$ & 3.44 & & & & - \\
\hline
\end{tabular}


Table $\mathrm{V}$ shows that there are differences in the role of electronic means in enhancing intellectual security according to the variable of the academic level between the two categories (first year and fourth year) on the one hand and the category (third and second year) from the other hand, where the differences are in favor of the category (third year) with an arithmetic mean of (3.60), while the arithmetic mean for the first year is (3.43) and the fourth year is (3.44). This result can be explained by the fact that first-year students are still at the beginning of their university life and have not interacted with electronic means sufficiently, and therefore they have not formed a framework of knowledge that qualifies them to be able to sort out the ideas and opinions presented to them, and they lack many critical thinking skills such as dialogue and criticism. Yet, we find fourth-year students rarely interact with electronic means because of their preoccupation with study and exams, being in the final stages of their university life. However, we find that the differences are in favor of thirdyear students, and this is explained by the fact that third-year students have the knowledge and intellectual framework that enables them to understand the contents of the electronic means presented to them and participate in it, and their ability to sort out the destructive ideas and opinions that threaten the security of society.

\section{XV.RECOMMENDATIONS}

In light of the above results, the study recommends employing electronic means in activating the intellectual security of university education students in Jordan, establishing programs that help students develop critical thinking so that they can sort out the ideas and opinions on electronic means and conducting other similar studies on the role of electronic means to include all public and private universities with the variables of this study and other variables unaddressed by this study.

\section{ACKNOWLEDGMENTS}

This Research is supported and funded by the by the Deanship of Scientific Research in The University of Jordan

\section{REFERENCES}

[1] Abu Khotwa, Sayed and Baz, Ahmed. (2014). The social network and its effects on intellectual security for university education students in the Kingdom of Bahrain. The Gulf University in the Kingdom of Bahrain, 7(15) 1-14.

[2] Abu Arja, Tayseer. (2000). Arab media: Challenges of the present and the future in the information age. Majdalawi Library: Cairo.
[3] Atribi, Howayda. (2011). The university's role in achieving intellectual security: A suggested concept. The Arab Journal for Security Studies and Training, 52 (27) 223-263.

[4] Danani, Abdul Malik. (2001). The media function of the Internet: A study to identify its uses in the field of media. University Salary House: Beirut.

[5] Jounson, Doug. (2005). Maintaining intellectual security in the Internet world, Learning and Leading with technology, 32 (8) 39-91.

[6] Kuppuswamy, S. and Narayan, P. (2010). The Impact of social networking websites on the education of youth, International Journal of Virtual Communities and Social Networking, 2(1), 67-79.

[7] Mabrouk, Sobha Bghoura. (2011), Intellectual security. Journal of Security and Life, 366 (2), Algeria.

[8] Rabei, Muhammad Bin Abdulaziz Salih. (2008). The Role of Curricula in Promoting the Concepts of Intellectual Security among University Students in the Kingdom of Saudi Arabia, a paper presented to the First National Conference on Intellectual Security "Concepts and Challenges".

[9] Radwan, Hanan and Ramadan, Salah, and Abdel-Wahhab, Iman. (2010). The role of modern communication technology in developing freedom of expression of opinion among university students in the light of the postmodern society, research presented to the first scientific conference of the Department of Foundations of Education, Education in Postmodern Society, College of Education, Benha University, 230-295.

[10] Sajit, Ahmad Mutashar. (2015), The extent to which Islamic education textbooks are included in the higher basic stage of concepts of intellectual security from the viewpoint of teachers in Jordan. [Master Thesis] Al-Bayt University, Jordan.

[11] Fakhouri, H. N., Hudaib, A., \& Sleit, A. (2019). Multivector particle swarm optimization algorithm. Soft Computing, 1-19.

[12] Shehata, Hassan. (2001). University education between theory and practice. Amoun: Nasr City.

[13] Hamad, F., Al-Fadel, M., \& Fakhouri, H. (2020). The effect of librarians' digital skills on technology acceptance in academic libraries in Jordan. Journal of Librarianship and Information Science, 0961000620966644.

[14] Shaltan, Fayez. (2013), The role of collages of education in Palestinian universities in enhancing intellectual security. Journal of the Islamic University for Educational and Psychological Studies, 11(1), 272-312.

[15] Fakhouri, H. N., Hudaib, A., \& Sleit, A. (2019, October). Hybrid Particle Swarm Optimization with Science Cosine Algorithm and Mathematical Equations for Enhancing Robot Path Planning. In International Conference on Information, Communication and Computing Technology (pp. 226-236). Springer, Cham.

[16] Alameri, J., Ismail, H. B., Akour, A., \& Fakhouri, H. N. (2019, October). Blended Learning and the Use of ICT Technology Perceptions Among University of Jordan Students. In International Conference on Information, Communication and Computing Technology (pp. 271-280). Springer, Cham.

[17] Shehri, Faiz Bin Ali Bin Abdullah. (2006), The role of secondary schools in spreading security awareness. [Master Thesis] Naif Arab University for Security Sciences, Riyadh. 